\title{
Byopa: A traditional headgear of Nyishi tribe from Arunachal Pradesh (India) and its relevance to Geographical Indication
}

\author{
G. Pangging ${ }^{1}$, M. Sharma, C.L. Sharma, N. Rai, J. Gogoi and Nyishi tribe \\ Department of Forestry, NERIST (Deemed to be University), \\ Nirjuli-791109, Arunachal Pradesh \\ ${ }^{1}$ Corresponding Author, e-mail: gpangging@gmail.com
}

[Received 02.04.2019; Revised 12.06.2019; Accepted 15.06.2019; Published 30.06.2019]

\begin{abstract}
Byopa, a traditional headgear of Nyishi tribe is considered as one of the most important cultural attire. It is generally worn during important socio-cultural occasions to symbolise the identity of the tribe. It is prepared from locally available materials viz., Calamus acanthospathus, C. erectus, Gmelina arborea, Alnus nepalensis etc. using handmade tools. Byopa may be considered for registration under Geographical Indication as it fulfilled all the prerequisite criteria of 'Geographical Indication of Goods (Registration and Protection) Act 1999'. Based on this act, this product belonged to Class 25 (Headgear) and the proof of origin of headgear was assured on the basis of secondary literature that proved that this traditional attire belonged to Nyishi tribe to represent their cultural identity. Uniqueness of the headgear with the use of wooden hornbill beak and other accessories indicate their unique intellectual property. The product was easily available and sold in the local markets due to its high demand in cultural practices.
\end{abstract}

Key words: Byopa, headgear, GI, Nyishi

\section{INTRODUCTION}

Nyishi tribe is one of the indigenous tribe of Arunachal Pradesh and who lives in close harmony with nature. They are dependent upon natural resources for all important aspects of their life such as food, shelter, medicine, magico-religious practices, socio-cultural practices etc. Of these, cultural attire made from the available forest resources plays an important part in their socio-cultural practices since many generations. Byopa, is one of the handmade cultural attire and is used as a traditional headgear. Earlier, it was traditionally worn by Priest $(N y u b)$ during magico-religious practices and also by other members in their day to day life. However, nowadays this cultural attire is worn occassionally, especially during auspicious ocassions like celebration of Nyishi day, Nyokum festivals and marriage celebration (Solanki et al. 2004; Kumar \& Riba 2015).

Traditionally, hornbill beak of Buceros bicornis, Rhyticeros undulatus and Aceros nipalensis were utilised by Nyishi tribe for the preparation of traditional headgear (Anonymous 2012; Krishna et al. 2012; Kumar \& Riba 2015). These birds were also hunted by other tribes like Idu Mishmis and Adis for their feather and skull in decoration purposes (Krishna et al. 2012).

Nyishi tribe also utilise different parts of other wild animals like Buceros bicornis, Selenarctos thibetanus, Macaca assamensis, M. mulatta etc. for decorating headgear and as symbolism. Now-a-days, original hornbill beak has been replaced by fibre glass and wooden materials due to conservation initiative taken by various NGOs like Wildlife Trust of India (WTI), WWF-India and NCF (Anonymous 2001; Dhar 2003; Anonymous 2012; Krishna 
et al. 2012; Basu 2016; Rahman 2016). This initiative is further strengthened in customary law by village council of Nyishi tribe with imposing fine for killing the hornbill birds (Rahman 2016). It is revealed that $60 \%$ of local people preferred artificial hornbill beak than original one. Again, $68 \%$ of local people prefer hornbill beak made of wood over plastic material (Kumar \& Riba 2015). The traditional headgears of the tribe have also higher market demand due to its cultural importance (Basu 2016). These are sold in various markets for their traditional importance, cultural identity, decorative and ethical values.

The protection of traditional knowledge especially their process and products is done through intellectual property right (IPR) that conforms Trade Related Aspects of Intellectual Property Rights of World Trade Organisation.

One of the IPR tools that protect the TKS and its product is by registration under provision of 'Geographical Indication of Goods (Registration and Protection) Act 1999'. In India, so far about 301 different products like agricultural, handicraft, textile products etc. are registered. The present study is an attempt to address the feasibility of Byopa, a traditional headgear as first GI product from Nyishi tribe of Arunachal Pradesh.

\section{MATERIALS AND METHODS}

\section{Study site and local community}

The study site was located in Papumpare district of Arunachal Pradesh. Its geographical area is $2,875 \mathrm{sq} \mathrm{km}$ with a total population of $1,76,385$ and is located between $26^{\circ} 55^{\prime} \mathrm{N}$ and $28^{\circ} 40^{\prime} \mathrm{N}$ latitudes and between $92^{\circ} 40^{\prime} \mathrm{E}$ and $94^{\circ} 21^{\prime} \mathrm{E}$ longitudes. Two main rivers i.e., Papum and Pare are the basis for naming Papumpare district. The study was conducted in Sagalee and Laporiang circle of Papumpare district due to availability of artisans.

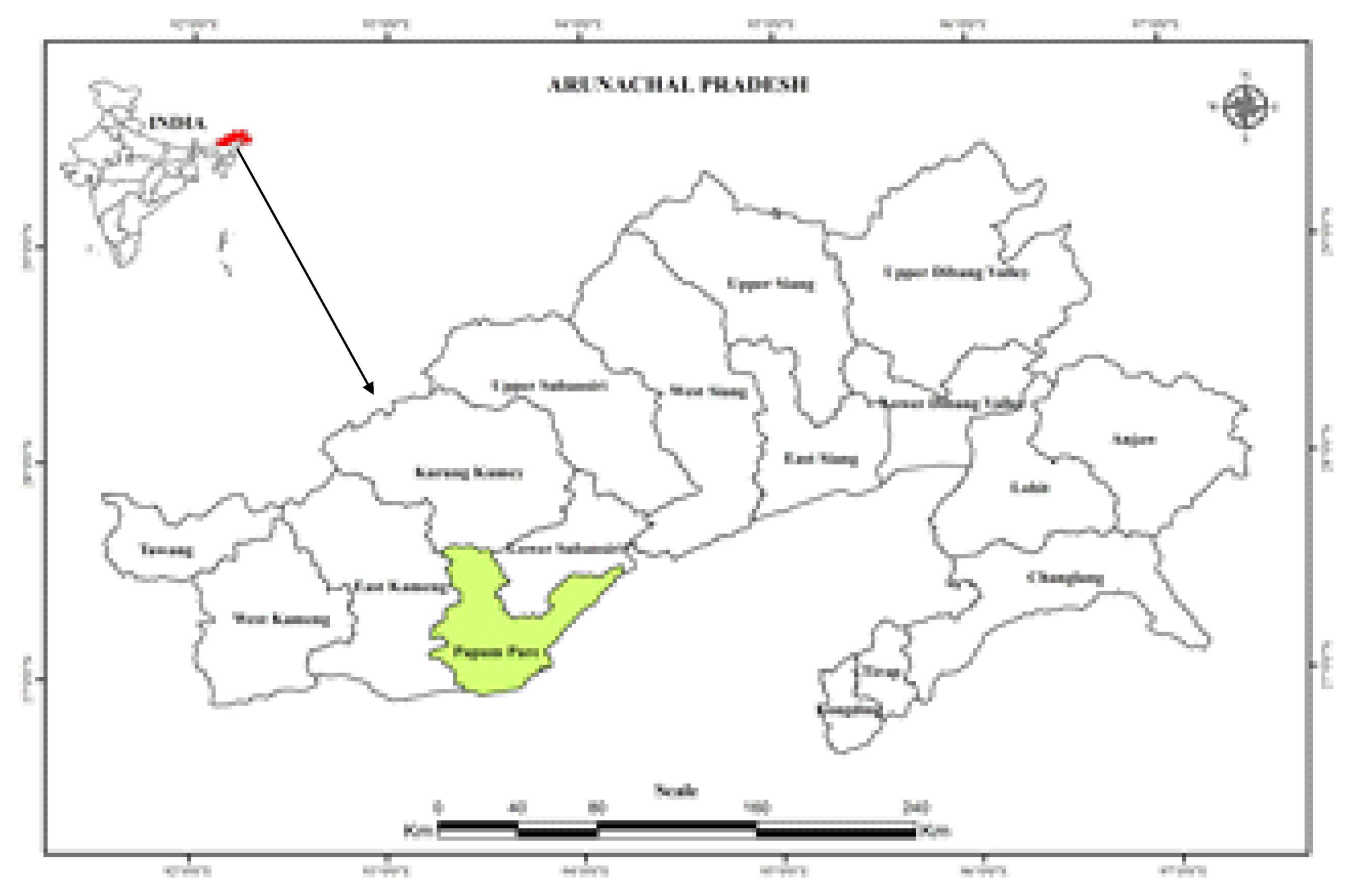

Figure 1. Location map of study area 
14 Byopa: traditional headgear of Nyishi tribe

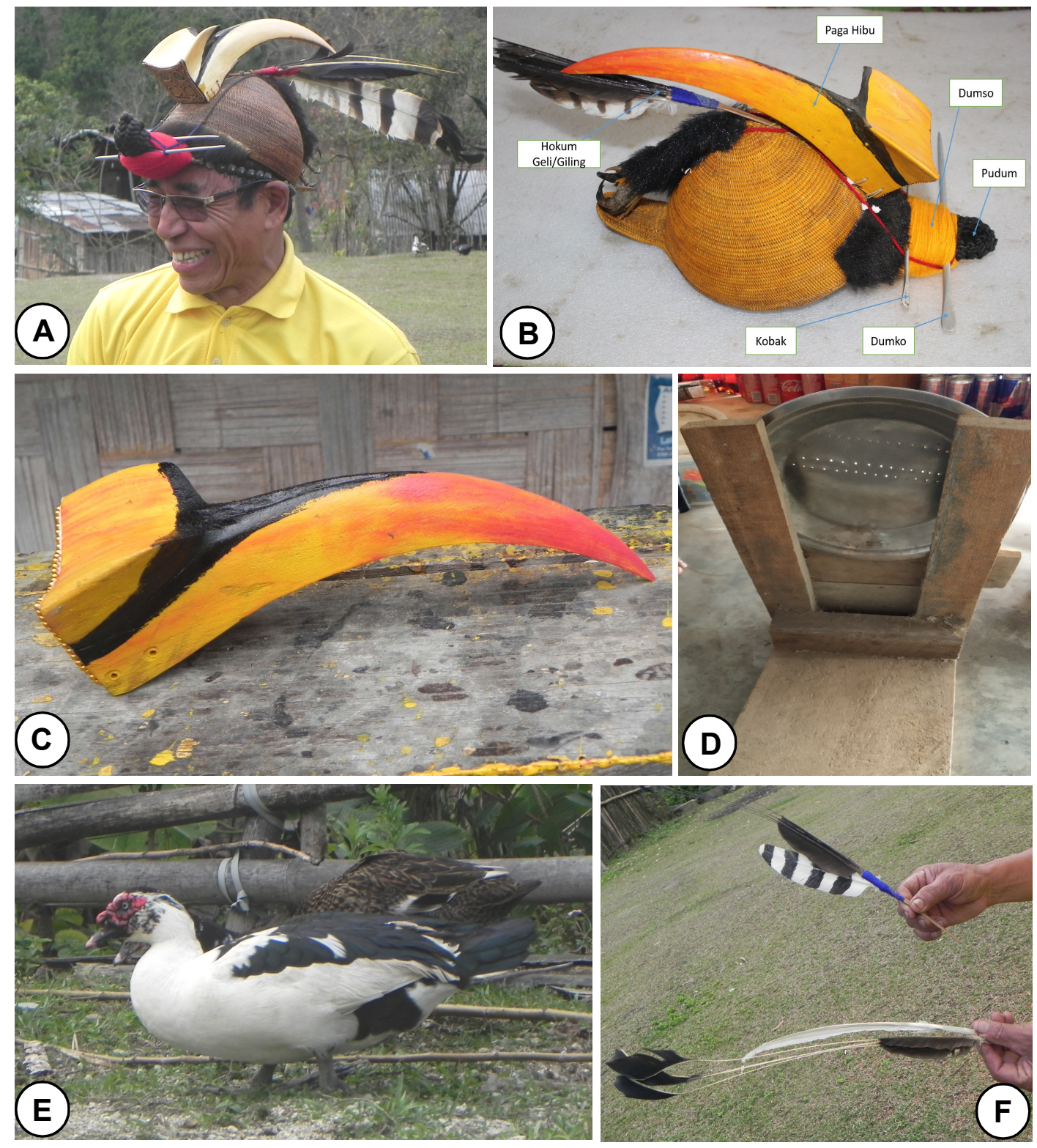

PLATE - I: A. Nyishi man wearing original Byopa; B. Description of Byopa; C. Wooden hornbill beak; D. Oso sennon; E. Domesticated Muscovy duck (Cairina moschata domestica); F. Feather of Muscovy duck as a substitute of hornbill feather and other birds

Tribe: Nyishi tribe is one of the dominant tribes of Arunachal Pradesh with a population of 249,824 (Census 2011) and is dominant in five districts of Arunachal Pradesh viz., East Kameng, Papum Pare, Lower Subansiri, Kurung Kumey, and Upper Subansiri and settled in some districts of Assam viz., Lakhimpur and Sonitpur. The Nyishi people belong to PaleoMongoloid stock and speak the Sino-Tibetan family language. The name 'Nyishi' is derived from two word $N y i-$ means man or human race and $I s h i-$ means hills or highland. Nyokum is the major festival of this tribe and is celebrated in the month of February. 
The study was conducted during April 2018 to February 2019 through the structured questionnaire in selected villages of Papumpare districts. Random sampling was adopted to document the importance of the traditional attire from artisans involved in preparation of traditional headgear. The feasibility of Byopa for GI registration was done by comparing the criteria provided in Geographical Indication of Goods (Registration and Protection) Act 1999.

\section{RESULTS AND DISCUSSION}

\section{Traditional method of headgear production}

Byopa, a traditional headgear of Nyishi tribe, is prepared by local artisans. The local name of head gear is derived from its main frame locally called Byopa which looks like a dome shaped cap with $20 \mathrm{~cm}$ diameter and with an extended part at posterior side (PLATE II). Now-a-days, they prepare headgear from locally available materials without using wildlife products due to conservation initiative done by NGOs and Forest Department. Most of the artisans involved in the making headgear are males. They utilised cane species like Calamus acanthospathus and C. erectus locally called Oso for this purpose. These species were used due to their strong and flexible stem which bend easily without breaking. The canes were seasoned through solar insolation and were splitted into two halves which were further split into $3 \mathrm{~mm}$ and $1-2 \mathrm{~mm}$ diameter sizes locally known as Pyalo and Somo respectively. The length of the Pyalo and Somo varies depending on their utility and were prepared from traditional tools namely traditional knife (Dao) and Oso sennan (a circular steel plate with smaller holes) (PLATE II). Oso sennan consisted of two main parts i.e., circular steel plate with numerous smaller holes fixed in a wooden frame used to prepare Pyalo and Somo.

Table 1. Details of parts of traditional headgear Byopa and their sources

\begin{tabular}{|l|l|l|l|}
\hline $\begin{array}{l}\text { Sl. } \\
\text { no. }\end{array}$ & $\begin{array}{l}\text { Local } \\
\text { Name }\end{array}$ & Material used & Description \\
\hline 1 & Podum & $\begin{array}{l}\text { Calamus acanthospathus, } \\
\text { C. erectus }\end{array}$ & Traditional cap made of cane \\
\hline 2 & Paga Hibu & $\begin{array}{l}\text { Wood (Gmelina arborea, }, \\
\text { Alnus nepalensis) }\end{array}$ & $\begin{array}{l}\text { The wooden hornbill beak fixed on the front portion of } \\
\text { traditional cap }\end{array}$ \\
\hline 3 & $\begin{array}{l}\text { Lunee } \\
\text { Gulu } \\
\text { Hokum } \\
\text { giling/geli }\end{array}$ & $\begin{array}{l}\text { Nowadays, feather of } \\
\text { domesticated muscovy } \\
\text { duck Cairina moschata } \\
\text { domestica } \text { are used }\end{array}$ & $\begin{array}{l}\text { Feather fixed along with hornbill beak towards posterior } \\
\text { side }\end{array}$ \\
\hline 5 & $\begin{array}{l}\text { Dum/ } \\
\text { Pudum }\end{array}$ & $\begin{array}{l}\text { Artificial hair } \\
\text { Yumso }\end{array}$ & $\begin{array}{l}\text { Yarn } \\
\text { earlier days, male tribe used to keep long hairs and tied } \\
\text { at the rear portion. However, nowadays it is replaced } \\
\text { with artificial hair }\end{array}$ \\
\hline 6 & $\begin{array}{l}\text { Dumation } \\
\text { It is used to wrap the artificial hair (Dum). Yellow, green } \\
\text { and red yarns are used for wrapping. Yarn wrapped on } \\
\text { hairs is locally called as Dumso }\end{array}$ \\
\hline 7 & $\begin{array}{l}\text { Dumko/ } \\
\text { Dumkyo }\end{array}$ & Aluminium/ bamboo & $\begin{array}{l}\text { It is a needle like structure fixed on Dumso } \text { and used to } \\
\text { tie hair at the forehead }\end{array}$ \\
\hline 8 & $\begin{array}{l}\text { Kobak } \\
\text { Aluminium/ bamboo }\end{array}$ & $\begin{array}{l}\text { It is similar to Dumko however its length is relatively } \\
\text { smaller. It is generally fixed along with Dumko on } \\
\text { Dumso. }\end{array}$ \\
\hline
\end{tabular}

Pyalo and Somo were the main components for preparing traditional headgear. Initially Somos were arranged vertically and Pyalo were weaved horizontally around Somo in perpendicular direction. The weaving of Somo were generally done with a needle, locally known as Silo or Piss. During weaving, relatively higher diameter of Pyalo was kept at the base of the cap and its diameter gradually decreased from base to the top to give the main frame of a dome shape. After completion, weaved headgear are painted and dried under sun followed by fixing accessories of traditional headgear with wooden hornbill beak, feather of domesticated duck etc. (Table 1; PLATE I). 

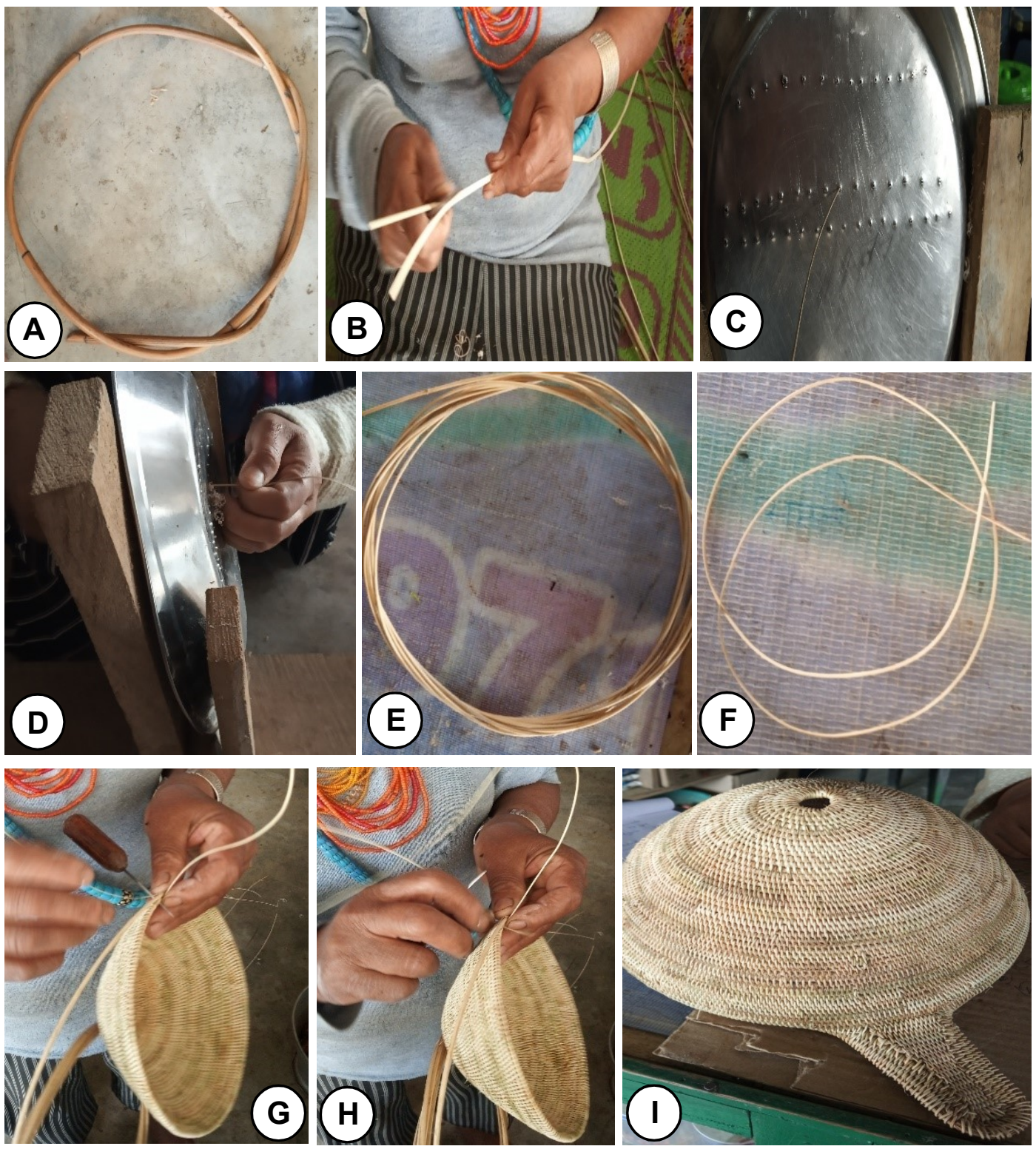

PLATE - II: A. Dried oso (Calamus spp.); B. splitting of Oso with help of Dao; C \& D. conversion of splitted oso into pyalo; E. Pyalo; F-Somo; G \& H. weaving of somo over pyalo using silo; I. Main frame.

The present study revealed that number of artisans involved in making headgear was only 15 in 5 villages under study (Figure 2)

The present study revealed that maximum number of artisans involved in making headgear varied from $1-5$ per village (Figure 2). It was observed that the number of making wooden hornbill beak per month varied from 40 to 300 depending on the involvement of an artisans. About 4 to 5 days were required to prepare a complete headgear (Byopa) and an artisan can prepare 3 to 4 Byopa per month. 


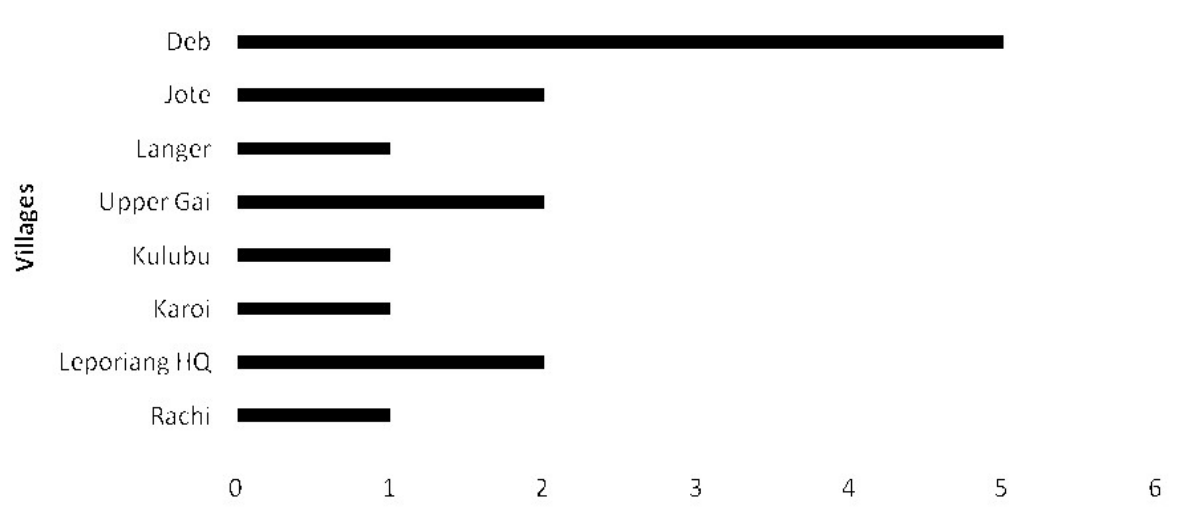

Figure 2. Number of artisans from eight villages involved in the preparation of headgear

\section{Relevance of GI in Byopa:}

GI play an important role to secure the identity of the product and provides legal protection and authenticity to it. GI also protects the produce against counterfeiting and unfair competition. The GI registration of Byopa will help to protect the cultural identity and IKS of Nyishi tribe. The present study shows that Byopa may be as considered one of the potential products for registration for GI as it fulfills the criteria given under Geographical Indication of Goods (Registration and Protection) Act 1999 as given below (Table 2).

Table 2. Conditions of GI satisfies by Byopa of Nyishi tribe

\begin{tabular}{|l|l|}
\hline Particular & \multicolumn{1}{c|}{ Details } \\
\hline Class of goods & Based on classification of goods under Class 25 (Headgear) of fourth schedule \\
\hline Proof of origin & $\begin{array}{l}\text { The place of its origin is Arunachal Pradesh and worn by Nyishi tribe. It is also } \\
\text { considered as cultural identity of the tribe (Anonymous 2001; Dhar 2003; Anonymous } \\
\text { 2012; Krishna } \text { et al. 2012; Basu 2016; Rahman 2016). The main reason of using beak of } \\
\text { horn bill is to symbolize Nyishi identity, manhood and vigourness (Anonymous 2001; } \\
\text { Mitra 2009; Anonymous 2019) }\end{array}$ \\
\hline Uniqueness & $\begin{array}{l}\text { Byopa is traditional headgear of Nyishi tribe and is a unique cultural attire with wooden } \\
\text { hornbill beak (Paga hibu), Podum, Lunee Gulu, Hokum giling/geli, Pudum, Dumso, } \\
\text { Dumko and Kobak }\end{array}$ \\
\hline Market demand & $\begin{array}{l}\text { It is easily available in local markets and is sold both as traditional attire and handicraft } \\
\text { items. The avarege maket price of headgear in local market is Rs. 2500 to 5000 }\end{array}$ \\
\hline $\begin{array}{l}\text { Association of } \\
\text { artisans }\end{array}$ & $\begin{array}{l}\text { No association of artisans was found which is one of the gap area and needs to be } \\
\text { addressed during registration of Byopa under Geographical Indication. }\end{array}$ \\
\hline
\end{tabular}

\section{Conclusions}

Byopa is an important cultural attire of Nyishi tribe of Arunachal Pradesh and is worn during special socio-cultural occasions. Byopa is one of potential cultural attires and need to be protected through Geographical Indication (GI) for the welfare of the artisans and local people. The headgear fulfils most of the criteria of Geographical Indication of Goods (Registration and Protection) Act 1999 and comes under class 25 of fourth schedule. The 
proof of origin and its use by a particular tribe was based on secondary literature. There was no association of artisans for this products an urgent need to make association before registration of Byopi under GI. This product is unique in NE region as hornbill beak and other accessories are not used in headgear in similar fashion by other tribes. It has high demand in market due to its cultural and decorative values. The GI tag on Byopa may help to protect the cultural identity and brand value.

\section{Acknowledgements}

The authors are thankful to Nyishi tribes of Papumpare district for their cooperation in providing information on traditional headgear. Authors are also thankful to National Mission on Himalaya Studies (NMHS), G.B. Pant National Institute of Himalayan Environment and Sustainable Development for providing financial support for this study.

\section{LITERATURE CITED}

Anonymous 2001. Fibreglass 'beaks' come to rescue of hornbills. Times of India. $3^{\text {rd }}$ September 2001. https://timesofindia.indiatimes.com/home/science/Fibreglass-beakscome-to-rescue-of-hornbills/articleshow/601610982.cms. Assessed on 14 ${ }^{\text {th }}$ March 2019.

Anonymous 2012. Artificial beaks help save the hornbills. http://indiasendangered.com/ artificial-beaks-help-save-the-hornbills/. Assessed on 14 ${ }^{\text {th }}$ March 2019.

Anonymous 2019. Synthetic beaks distributed for hornbill conservation in Arunachal Pradesh. https://www.wti.org.in/news/synthetic-beaks-distributed-for-hornbill-conservation-inarunachal-pradesh/. Assessed on $14^{\text {th }}$ March 2019.

Basu, M. 2016. A tribe of hornbill hunters turns to conservation. The Scientist. $1^{\text {st }}$ September 2019. https://www.the-scientist.com/notebook/a-tribe-of-hornbill-hunters-turns-toconservation-32938. Assessed on 14 ${ }^{\text {th }}$ March, 2019.

Census 2011: Census of India- 2011, Arunachal Pradesh, Series 13, Part XII-A. District Census Book: Papumpare. Directorate of Census Operation, Arunachal Pradesh.

Dhar, A. 2003. Now, fiberglass 'beaks'. The Hindu. $18^{\text {th }}$ December, 2003. https:// www.thehindu.com/2003/12/18/stories/2003121802592400.htm. Assessed on $14^{\text {th }}$ March 2019.

Krishna, C.M.; Sarma, K \& Kumar, A. 2012. Rapid assessment of Wreathed Hornbill Aceros undulates (Aves: Bucerotidae) populations and conservation issues in fragmannted lowland forests of Arunachal Pradesh, India. J. Threat. Taxa 4(14): 3342 - 3348.

Kumar, A \& Riba, B. 2015. Assessment of effectiveness of conservation action adopted for hornbill species in Arunachal Pradesh, India: The great Indian hornbill (Buceros bicornis). Intn. J. Consv. Sci. 6(1): 125 - 134.

Mitra, N. 2009. Nyishi no more a threat to hornbills. https:/timesofindia.indiatimes.com/city/ guwahati/Nyishis-no-more-a-threat-to-hornbills/articleshow/4614194.cms. Assessed on $14^{\text {th }}$ March 2019.

Rahman, A. P. 2016. Hunters turn protectors of threatened hornbills in northeast India. Thehirdpole.net. Understanding Asia's water crisis. December 7, 2016. https:// thewire.in/environment/hunters-turn-protectors-of-threatened-hornbills-in-northeastindia. Assessed on 14 ${ }^{\text {th }}$ March 2019.

Solanki, G.S., Chutia, P. \& Singh, O.P. 2004. Headgear-A cultural artefact and its impact on biodiversity in Arunachal Pradesh. Arunachal Univ. Res. J. 7(1): 35 - 44. 